\title{
Managing the digital campaign process for sustainable tourism destinations
}

\author{
Y. Y. Liu \& A. Mačerinskienè \\ Faculty of Economics, Vilnius University, Lithuania
}

\begin{abstract}
This paper was developed reviewing literature and presenting frontiers of sustainable tourism destinations and marketing. This paper discusses (1) the process of managing a digital campaign for sustainable tourism destination, with its five steps, i.e., designing the digital campaign, selecting the digital platforms, measuring the performance of digital platforms, evaluating the effectiveness of digital campaign, and making decisions; (2) two models created by authors, i.e. a model of tourist sustainability empathy, and a model of tourist experience integration; (3) two recent issues related to sustainable tourism and its marketing, i.e., Web 3.0 technology and the Marketing 3.0 discipline; and (4) recommendations for future research in the area of sustainable tourism and its marketing. This paper fills the gap between digital campaigns and sustainable tourism, and provides marketers with skills, tools, and marketing methods for sustainable tourism destinations.
\end{abstract}

Keywords: sustainable tourism, destination, sustainable tourism marketing, digital campaign, and digital marketing.

\section{Introduction}

Today, two stimuli are driving the world: Web 3.0 technology and the philosophy of sustainable development. People's behaviour, references, and the spirit behind their actions have changed greatly. The former makes it possible for computers to intelligently interpret human information and preferences by web analytics and thus generate content tailored to the needs of users. The latter, on the other hand, makes the entire human society develop towards an environmental-social-economical and friendly/beneficial way, for both current and coming generations. Thus, under such a contemporary background, two 
main topics will be discussed in this paper: marketing skills at the time of Marketing 3.0 and its application to sustainable tourism destinations. Sustainable tourism destinations will be treated as one type of tourism 'product', digital campaign as 'promotion', and digital platform(s) as 'channel(s)'. After understanding the unique features of the product and its promotion channel, there should be skills and tools to manage the process of its promotion and evaluation of the performances.

\section{Literature review}

\subsection{Sustainable tourism, sustainability, and sustainable tourism destinations (STD)}

During the last ten years, there was a wide range of debates on sustainable tourism, and it has been discussed widely: its definitions (Hunter [1]; Hind and Mitchell [2]), evaluation of its positive and negative impacts regarding environmental, socio-cultural, and economic respects (Hunter [3]; Schianetz and Kavanagh [4]), and the focus on environmental protection and resource management (Vaughan and Ardoin [5]).

Until now, sustainable tourism was discussed as a focus on the balance of the "triple bottom line", i.e., environment, socio-culture, and economics (Long et al. [6]; Stoddard et al. [7]; Torres-Delgado and Palomeque [8]).

Nowadays research has shifted to focus elsewhere: tourist behaviours and attitudes (Budeanu [9]; Choi and Sirakaya [10]) and tourist views of understanding sustainable tourist consumption behaviour (Budeanu [9]; Cottrell et al. [11]; Deng and Li [12]; Ghaderi and Henderson [13]; Ho et al. [14]; Mustika et al. [15]); the extent to which sustainable dimensions are associated with tourists' experiences by understanding their potential behaviour and motivation as factors for success and promotion in the tourism market (Liu et al. [16]); the ways in which personal psychological values, motivations (Ho et al. [14]), tourist satisfaction, willingness to recommend their sustainable tourism experiences (Mustika et al. [15]), and self-identification of ecotourists (Deng and $\mathrm{Li}$ [12]); as well as sustainable tourism benefiting nations, and marketing programs for its regional economic success (Pulido-Fernández et al. [17]).

Researchers began to consider that sustainability should be a concept applied to all types of tourism and environment (Saarinen [18]). With the advocacy of sustainability, studies have begun to focus on rural tourism (MacDonald and Jolliffe [19]), evaluations and indicators of sustainability (Schianetz and Kavanagh [4]), and the challenges of applying sustainability in tourism sector in a practical and useful way (Liu [20]; Saariene [18]; Sharpley [21]).

Elbe [22] defined destination as a geographical tourist endpoint, be it a country, region, city, or village. It is the geographical room that offers tourists the complete tourist product. The sustainable tourism destination is one type of tourist products. The attractions of a sustainable tourism destination provide the motivation for the trip, whereas the facilities make it possible, and it is the combination of the two that creates the complete tourist experience (von 
Friedrichs Grängsjö [23]). There is also an issue of seasonal demand for sustainable tourism destinations, which makes it difficult to achieve economic, social, or environmental sustainability on a yearly basis (Sörensson and Friedrichs [24]).

Contemporary issues, for example, the International Conference on Sustainable Tourism, since 2004, together with its participants presented featured topics of sustainable tourism, such as: strategies, protected areas, infrastructure and hotels, IT, transportation, environmental risk, as well as surveys and analysis. All these are included in its conference proceedings from Sustainable Tourism to Sustainable Tourism VI (edited by Brebbia and Pineda [25], and by Brebbia et al. [26]).

\subsection{Tourist attitudes, sustainability empathy, and experience integration towards sustainable tourism, as well as models and conclusions developed from the literature}

\subsubsection{Tourist attitudes towards sustainable tourism}

Schultz et al. [27] identified the connection between people's attitudes towards nature and their attitudes towards environmental issues. The degree to which an individual is willing to associate himself or herself with nature is directly related to the type of attitudes that he/she develops. It is also argued that an individual's beliefs about nature and the human role in it are a fundamental component of his or her belief system in relation to the environment (Dunlap et al. [28]). Xu and Fox [29] stated that people's attitudes to conservation have a mediating effect between attitudes towards nature and their support for sustainable tourism and thus it is important to concentrate on people's conservation attitudes and encourage ecocentric tourism activities, such as ecotourism and wildlife tourism.

\subsubsection{Tourist sustainability empathy}

Bandura's Social Cognitive Theory (SCT) [30-33] argued that people's motivations behind sustainable tourism and types of sustainable actions performed depend on their empathy towards sustainability. Repeated and enhanced mindfulness of a place and its people's long-term wellbeing can create in a person a sense of care, connectedness, belonging, and a bond with that place, which results in empathy. Thus, sustainability empathy is defined as one's ability to establish an emotional connection with the surrounding people and environment. The concept of empathy was applied to explain how tourism marketers make sense of what sustainability means to them as a result of their background and motivations (Font et al. [34]).

According to the literature, the model of tourist sustainability empathy was created by article authors to present the interrelationship among tourists' attachment to a specific place, its people and wellbeing, sense of care, connectedness, belonging, and bond, tourist sustainability empathy and motivations to choose a sustainable tourism destination as a product to consume (shown in Figure 1). 


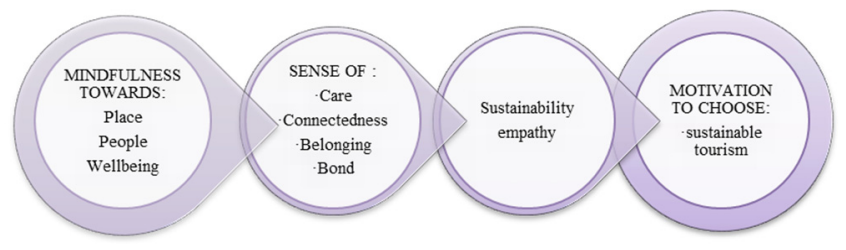

Figure 1: Model of tourist sustainability empathy.

\subsubsection{Tourist experience integration}

From the perspective of the tourist consumption process (Ryan [35]; Williams and Buswell [36]), tourist behaviour is an aggregated term that includes pre-visit decision-making, onsite experience, experience evaluations, and post-visit behavioural intentions and behaviours. Studies in specific areas of tourism have accepted the positive relationship among tourism motivation, experience, satisfaction, and behavioural intention (Ballantyne et al. [37]; Liang and Tsai [38]; Williams and Soutar [39]). Moreover, experience quality refers to the psychological outcome that results from customer participation in tourism activities (Kao et al. [40]).

According to the literature, the model of tourist experience integration was created by article authors to present the experience of tourism consumption cycle from pre-visit decision making to on-site experience, experience evaluation, post-visit behavioural intention and behaviours, within tourists' psychological development from sustainable tourism destination (STD) motivation to the experience during their visit, satisfaction evaluation, and behavioural intention, with the experience quality as a core issue of the model (shown in Figure 2).

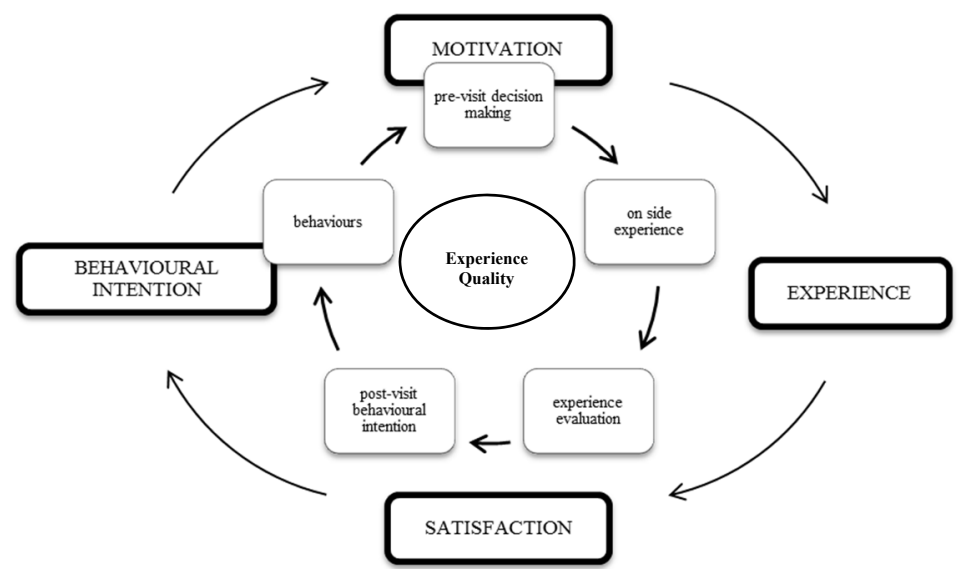

Figure 2: Model of tourist experience integration. 


\subsubsection{Conclusions from the literature review}

First, people's attitudes are shaped within a specific social environment under which social norms and values are developed. People will define their own roles as human and their attitudes hold within such an environment and their beliefs. Meanwhile, people's attitudes towards conservation result in the attitudes towards nature, and then the attitudes towards sustainable tourism. Second, people's attachment to a place, and its people and wellbeing will result in senses of care, connectedness, belonging and bond, which shapes people's sustainability empathy. And the sustainability empathy will motivate people's choice towards sustainable tourism. Third, there are actually two cycles of people's consumption of sustainable tourism. One is the psychological cycle of consuming behaviour and the other is the consumption behaviour process, and the experience quality will be the core issue resulting in people's satisfaction and willingness to repeat and recommendation of their visit to STD.

Thus sustainable tourism is an association and integration of social values, norms, and tourist attitudes under such social environment as well as their motivation and consumption behaviours. Those are key factors for success and promotion of a STD.

\subsection{Social media, social networking, digital campaign, STD marketing, and conclusions from the literature review}

Because the revolution of Web 1.0 to Web 2.0 and Web 3.0 is essential to this paper and much of the literature involved Web 2.0, the technological revolution from Web 1.0 to Web 3.0 (Choudhury [41]) is presented.

Table 1: $\quad$ Features of Web 1.0, Web 2.0, and Web 3.0.

\begin{tabular}{|c|l|}
\hline Web 1.0 & Read-only, little interaction for information exchange (readable) \\
\hline Web 2.0 & Read-write, connecting people, involving participatory media (writable) \\
\hline Web 3.0 & $\begin{array}{l}\text { Create a world wide database, analyse people's behaviour and } \\
\text { preferences, and predict people's behavioural intentions (executable) }\end{array}$ \\
\hline
\end{tabular}

Kaplan and Haenlein [42] defined social media as "a group of Internet-based applications that build on the ideological and technological foundations of Web 2.0 , and that allow the creation and exchange of user-generated content". Cohen [43] summarized 30 different definitions of social media from different perspectives, emphasizing important characteristics and natures of social media, such as online tools, applications, platforms and media, depending on information technologies (IT); social media are peer-to-peer communication channels enabling interactive web's content creation, collaboration, and exchange by participants; and social media link users to form a virtual community by using cross-platforms and affect people's behaviours and real life. In addition to Cohen's [43] categorization of social media definition and natures, Krumay and Brandtweiner have stressed e-loyalty in virtual communities 
(Krumay et al. [44]). Social media would decrease uncertainty and increase the exchange utility on the other hand, and provide users a sense of belonging into virtual travel communities by storytelling (Gretzel et al. [45]; Wang et al. [46]).

The term social networking needs to be considered alongside with the term social media (Zeng and Gerritsen [47]). Social networking was defined as an online service, platform, or site that focus on facilitating the building of social networks or social relations among people who share interests, activities, backgrounds, or a real-life connection.

Social media plays an increasingly important role in many aspects of tourism, especially in information search and decision-making behaviours (Fotis [48]), tourism promotion (Bradbury [49]), and focusing on best practice for interactivity with consumers via social media channels (e.g., social sharing of holiday experiences) (Zeng and Gerritsen [47]).

Thus a digital campaign for STD uses targeted, measurable, and interactive marketing tactics to promote a STD as a product, and uses digital technologies to reach and convert leads into customers and retain them through digital platforms.

Leveraging off social media to market tourism products has proven to be an excellent strategy (Fotis [48]). Many countries regard social media as an important tool to promote their tourism industries (Zeng and Gerritsen [47]). Shared information on social media sites is recognized as an important information source that may help tourists plan travels or even eventually influence potential travellers' decision-making (Zeng and Gerritsen [47]). The engagement of social media has fundamentally changed the way individuals plan and consume travel (Gretzel and Yoo [50]; Hudson and Thal [51]). On the other hand, social networking users seem likely to increase awareness of the impact of travel behaviours and of more sustainable alternatives (Zeng and Gerritsen [47]). For example, Kane et al. [52] indicated that Facebook represents an effective and innovative environment that could build necessary links between green attitudes and consumers' hearts and minds. This may not directly lead to a change in travel behaviours, but it potentially influences attitudes and values that could change travel behaviours in the longer term (Zeng and Gerritsen [47]).

In tourism studies, growing research has emphasized the role of electronic Word-of-Mouth (eWOM) in tourism marketing and its information diffusion online (Litvin et al. [53]; Park and Gretzel [54]; Zhu and Lai [55]), focusing on specific issues such as the influence of eWOM on travel decisions (Black and Kelley [56]; Mauri and Minazzi [57]; Patterson [58]) and the marketing potential of tourist generated content as eWOM (Confente [59]; Tussyadiah et al. [60]). Furthermore, the diffusion of information on social media was defined as a phenomenon that a message is transmitted from one actor to other actors by forwarding in the context of social media such as Twitter and Facebook (Kim et al. [61]; Kwon et al. [62]).

Marketing has moved from being product-centric (Marketing 1.0) to being consumer-centric (Marketing 2.0). Marketing 3.0 is the stage in the arena of human aspirations, values, and spirit. Marketing 3.0 complements emotional marketing with human spirit marketing. Today, we are in the age of participation, the age of globalization paradox, and the age of creative society, consumers are 
more collaborative, cultural, and human spirit-driven. The rapidly growing forms of social media have empowered consumers (Kotler et al. [63]).

Table 2: $\quad$ Marketing 1.0, Marketing 2.0, and Marketing 3.0.

\begin{tabular}{|l|l|}
\hline Marketing 1.0 & Product-centric, transaction and sales oriented \\
\hline Marketing 2.0 & Consumer-centric, relationship oriented \\
\hline Marketing 3.0 & $\begin{array}{l}\text { Human-centric, value driven, inviting consumers to } \\
\text { participate in the company's development of products } \\
\text { and communication }\end{array}$ \\
\hline
\end{tabular}

\subsubsection{Conclusions developed from the literature}

There is no doubt that the advent of information and communication technologies (ICTs) has changed the way tourists choose and pay for their travels and enabled travellers to share their experiences. Social media would decrease uncertainty and increase the exchange utility on one hand, and provide users a sense of belonging into virtual travel communities by storytelling on the other hand (Gretzel et al. [45]; Wang et al. [46]). A digital campaign, as one method of promotion, is more useful for generating public concerns and promoting awareness of the STD. However, the questions that remains unanswered are how to choose the right channels or technologies to launch STD as a product, which is (are) the most efficient channel(s), what are the key performance indicators (KPIs) to evaluate the digital channels' performances? What is the process of a digital campaign of STD, and how to manage it?

\section{Main theoretical findings}

There were two main terms of the study: sustainable tourism destination (STD) and the digital campaign for STD. To better develop and generate the idea of the study, closely related topics were added to each term: literature on sustainable tourism and sustainability were added to STD, while literature on social media, social networking, the Web $1.0-$ Web 3.0 revolution and Marketing 1.0 Marketing 3.0 were added to the digital campaign for STD.

This study was developed based on literature review of sustainable tourism destinations (STD), digital campaign, and their closely related topics. We read 217 articles and 99 of them were closely related to the chosen topics. The literature presented most topics concerned in the field of sustainable tourism destinations and digital campaign, and models were created according to the literature to develop and support the main body of the study. In other words, the main body of the study, "managing the digital campaign process for sustainable tourism destinations", was divided into five parts, and each part represents a step.

The study revealed the interrelationships among several most concerned contemporary questions about the digital campaign of sustainable tourism destinations (STD). 
$\sqrt{ }$ What is (are) the main aim(s) of the digital campaign of STD?

$\sqrt{ }$ Which digital platforms (social media) are to be selected to launch the digital campaign of STD?

$\sqrt{ }$ What are the criteria to evaluate the performance your digital partner(s)?

$\sqrt{ }$ Which contribution is made by your digital partners?

$\sqrt{ }$ What to do next?

However, those questions are not independent. Instead, they are interconnected. All these questions together will answer the main body of the study: how to manage the digital campaign process of STD? These questions can be illustrated by connecting them into a sequential model (shown as Figure 3 ).

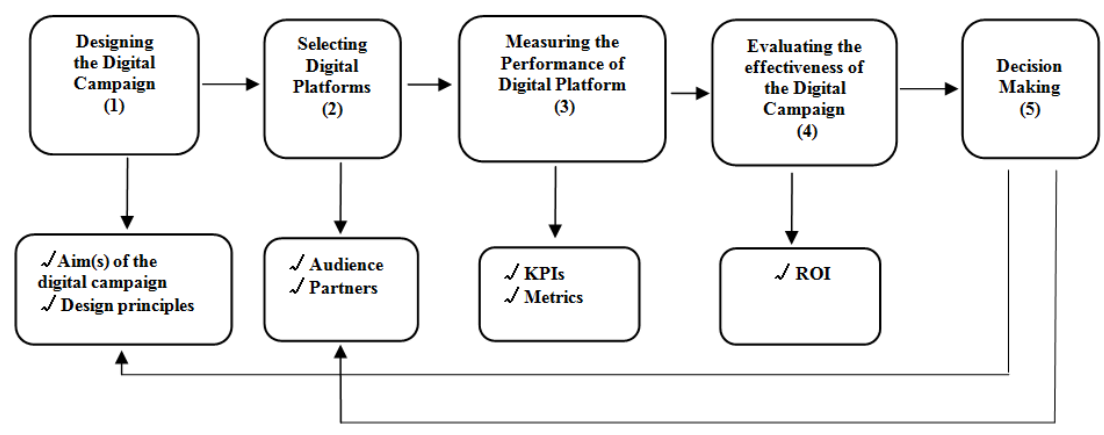

Figure 3: The digital campaign process for sustainable tourism destinations.

\section{Methodology}

\subsection{Designing the digital campaign}

Without aim(s) the results cannot be measured. In order to measure and evaluate the performance of the digital campaign, aims should be set at the very beginning. Like any other marketing methods, the digital campaign should be able to promote the STD and enlarge the economic income of the STD. However, for one thing, economic income is only one concern of STD; also, digital campaigns normally perform better with increasing public awareness of the STD.

\subsubsection{What are the principles of designing an effective digital campaign?}

There are several issues generated by the literature concerning tourist attitudes towards sustainable tourism, tourist sustainability empathy and tourist experience integration. Principles of an effective digital campaign design should be able to (1) increase public awareness of green values, (2) create social norms and an atmosphere of care towards nature, (3) evoke emotions towards sustainability, (4) shape attitudes towards sustainability, (5) encourage sharing recommendations, and (6) lead to repeat visits.

Tourist experience is unique, emotionally charged, and of high personal value (Mcintosh and Siggs [65]), and there is a positive relationship among travel 
experience, satisfaction, and behavioural intention to come back and willingness to recommend (Liu et al. [16]). It is important for the design to leave the possibility for interactive eWOM communication from the audience to share the previous travel experiences. Moreover, information diffusion factors, such as, language and cross-culture issues should be taken into consideration during the design process. In addition to the principles listed, another key issue is to avoid information overload so as to design a persuasive and influential digital campaign.

\subsection{Selecting digital platforms}

Selecting digital platforms to launch the digital campaign is important for marketers. Digital platforms refer to the social media channels which marketers will co-operate with to promote the designed digital campaign and get feedback from the audience.

Like traditional marketing channels, the chosen digital platforms will lead the STD to specific groups of audience. Marketers still need to consider using right digital platforms to reach the targeted audience, although today the internet may be able to lead the digital campaign to everyone all over the world. In addition, there is the other issue of people's access to digital platforms, e.g., China's limited access to Facebook or Twitter. However, there are specific digital platforms in China, such as Wechat, QQ, Renren, Sina weibo, etc.

Concerning how many digital platforms should be selected to co-operate with is not a big issue any more as one of the biggest advantages of social media is the decreased cost of promoting products. Top 10 most popular social networking sites as digital platforms in 2016 are shown in the table below.

Table 3: Top 10 most popular social networking sites (source: http://www.ebizmba.com/articles/social-networking-websites).

\begin{tabular}{|c|c|c|c|}
\hline 1 & Facebook & 6 & Tumblr \\
\hline 2 & Twitter & 7 & Instagram \\
\hline 3 & LinkedIn & 8 & VK \\
\hline 4 & Pinterest & 9 & Flickr \\
\hline 5 & Google Plus + & 10 & Vine \\
\hline
\end{tabular}

\subsection{Measuring digital platform performance}

Measuring the performance of a digital platform means measuring its ability to interact with an audience, and how the audience responds.

Key performance indicators (KPIs) and metrics are measurements or indicators to measure the degree to which different standards or criteria have been achieved. For example, according to Florès [64], one of the web metrics is to measure people's attention, interest, desire, and action. The KPIs to evaluate people's attention to a digital campaign will be three indicators: the number of unique visitors, the number of visits, and the number of page views. The KPIs to 
evaluate people's desire will be two indicators: the number of visitors and share of first and repeat visitors. The KPIs to evaluate people's interest will be five indicators: average duration of the visit, number of visits per person, average number of page views per visit, most visited pages, and bounce rate. The KPIs to evaluate people's action will be two indicators: the click-through rate and the conversion rate(s).

According to different standards (criteria), there will be different ways to define different web metrics and different KPIs of the metrics. However, those are the ways to assess the success of a digital campaign.

\subsection{Evaluating the effectiveness of a digital campaign}

Has (have) your aim(s) been achieved? Evaluating digital campaign effectiveness means measuring its performance and contributions to the results. Being effective indicates producing expected results, achieving agreed aims in time. Aims can be quantity, quality, timeliness, costs or profitability. The aims of a digital campaign can be increasing awareness, drawing attention to STD images, creating social value and norms towards sustainability, enhancing tourist loyalty or commitment to sharing previous travel experience, or simply enlarging sales and benefits. Have the anticipated aims achieved? Thus, marketers should assess the results of the digital campaign with the set aims. Return of investment (ROI) is the term to evaluate the balance between input and output of the digital campaign.

However, the input of the digital campaign can be money, human resources, time, and many other resources supporting the activities. And the output of the digital campaign can be both measurable and immeasurable. Those measurable might be direct indicators such as sales, economic increase, or the number of visitors to the STD. Meanwhile, those immeasurable might be indirect indicators such as awareness, social value and norms, sustainability empathy, or attitudes. Those indirect indicators will turn to direct indicators in a long term.

\subsection{Decision making}

Decision makers cannot manage what cannot be measured or evaluated. Measurement and evaluation allow marketers to balance the set objectives and results and think about the problem or go on with the success. Either a successful digital campaign process or a failure in design, its contents will result in a start from the first step of the next round. However, failure to find or co-operate with digital partners will shape the second round from selecting digital platforms.

\section{Discussion and implications}

Triggering spiritual resonance with consumers and conveying sentiments of products are two main themes in the time of Marketing 3.0. Products and services, tangible and intangible, are not merely considered to meet consumer needs and desires, but to proactively lead consumers to achieve their spiritual enjoyment. Marketers and their strategies should be human centric and value 
driven, and invite consumers to engage in the company's development of products and communication as well. Marketing 3.0 requires marketing strategies and tactics to operate in a more spiritual way.

A sustainable tourism destination (STD), as a special product of tourism, has its unique features and a nature of sustainability, which emphasizes more on social and personal values and norms, as well as attitudes towards a greener future and younger generations. STD as a product has a deeper focus on spiritual comfort. Meanwhile, digital platforms are the channels that look for interactive communication with consumers and look forward to consumers' sharing, engaging, and committing. Thus, the strategy with tactics, products, and channels happens to coincide with a spiritual perspective. It will be evident that they are using the right tool for correct segmentation in a precise way when marketers of a STD apply a digital campaign to connect the destination with specifically targeted consumers, both current and potential.

Being different from traditional marketing tactics, digital campaigns are combining information technologies with communication skills to effectively develop and spread messages, proposition and advocacies to capture targeted segmentation. Clear goals, contagious design, powerful social networking, launch, data analysis and analytics are important parts of the digital campaigns.

Today, our lives have been deeply influenced and changed by information and communication technologies (ICTs). Web 3.0 will not be the end of the development of ICTs. Both marketers and consumers may benefit by the development of ICTs. Both marketers and consumers will pay attention to the focus of knowing themselves and knowing each other. The preferences, intentions, and responses of both supply and demand side will be analysed and the analysis will be sent to each other by technology. It is technology that makes the transparent future easier, although many of us will still debate on getting benefited and being tracked by the advanced technologies.

Future research into digital campaign and tourism might find new interests in four areas: (1) communication as a mediation between digital campaigns and tourism, including topics about attitudes, motivation, value, or trust; (2) branding destinations, including topics about image, identity, and the integrity of the destination brand; (3) information diffusion through digital platforms; and, (4) technologies and tools to analyse the performance of digital platforms or their ability to serve specific aims of digital marketing. Moreover, those three models of tourist attitudes towards sustainable tourism, tourist sustainability empathy and tourist experience integration may be further studies. Last but not least, Web 3.0 and Marketing 3.0 related research is still relatively new in the area of sustainable tourism and its marketing.

\section{References}

[1] Hunter, C. (2002). Aspects of the sustainable tourism debate from a natural resources perspective. In: R. Harris, T. Griffin, \& P. Williams (Eds), Sustainable Tourism: A global perspective. Oxford: Butterworth Heinemann. 
[2] Hind, D., Mitchell, J. (2004).Sustainable Tourism in English Lake District. Sunderland: Business Education Publishers.

[3] Hunter, C. (2002). Sustainable tourism and the touristic ecological footprint. Environment, Development and Sustainability, 4(1), 7-20.

[4] Schianetz, K., Kavanagh, L. (2008). Sustainable indicators for tourism destinations: A complex adaptive systems approach using systemic indicator systems. Journal of Sustainable Tourism, 16(6), 601-628.

[5] Vaughan, M.B., Ardoin, N.M.(2014). The implications of differing tourist/resident perceptions for community-based resource management: A Hawaiian costal resource area study. Journal of Sustainable Tourism, 22 (1), 50-68.

[6] Long, J., Vogelaar, A., Hale, B. W. (2014).Toward sustainable educational travel. Journal of Sustainable Tourism, 22(3), 421-439.

[7] Stoddard, J.E., Pollard, C.E., Michael, R. (2012). The triple bottom line: A framework for sustainable tourism management. International Journal of Hospitality \& Tourism Administration, 13(3), 233-258.

[8] Torres-Delgado, A., Palomeque, F. L. (2014).Measuring sustainable tourism at the municipal level. Annals of Tourism Research, 49, 122-137.

[9] Budeanu, A. (2007). Sustainable tourist behaviour - a discussion of opportunities for change. International Journal of Consumer Studies 31(5), 499-508.

[10] Choi, H. C., \& Sirakaya, E. (2005). Measuring residents' attitude toward sustainable tourism: Development of Sustainable Tourism Attitude Scale. Journal of Travel Research, 43(4), 380-394.

[11] Cottrell, S. P., Vaske, J. J., Roemer, J. M. (2013). Resident satisfaction with sustainable tourism: The case of Frankenwald Nature Park, Germany. Tourism Management Perspectives, 8, 42-48.

[12] Deng, J., \& Li, J. (2015)/ Self-identification of ecotourists. Journal of Sustainable Tourism, 23(2), 255-279.

[13] Ghaderi, Z., \& Henderson, J. C. (2012). Sustainable rural tourism in Iran: A perspective from Hawraman Village. Tourism Management Perspectives, 47-54.

[14] Ho, C.I., Liao, T.Y., Huangh, S.C., Chen, H.M. (2014). Beyond environmental concerns: Using means-end chains to explore the personal psychological values and motivations of leisure/recreational cyclists. Journal of Sustainable Tourism, 23(2), 234-254.

[15] Mustika, P. L. K., Birtles, A., Everingham, Y., Marsh, H. (2013). The human dimensions of wildlife tourism in a developing country: Watching spinner dolphins at Lovina, Bali, Indonesia. Journal of Sustainable Tourism, 21(2), 229-251.

[16] Liu, C. H. S, Horng, J. S., Chou, S. F. (2015). A critical evaluation of sustainable tourism from the integrated perspective: Conducting moderated-mediation analysis. Tourism Management Perspectives, 16, 43-50.

[17] Pulido-Fernández, J. I., Andrades-Caldito, L., Sánchez-Rivero, M. (2015). Is sustainable tourism an obstacle to the economic performance of the 
tourism industry? Evidence from an international empirical study. Journal of Sustainable Tourism, 23(1), 47-64.

[18] Saarinen, J. (2006). Traditions of sustainability in tourism studies. Annals of Tourism Research, 33(4), 1121-1140.

[19] MacDonald, R., Jolliffe, L. (2003). Cultural rural tourism: Evidence from Canada. Annals of Tourism Research, 30(2), 307-322.

[20] Liu, Z. (2003). Sustainable tourism development: a critique. Journal of Sustainable Tourism, 11(6), 459-475.

[21] Sharpley, R. (2000). Tourism and sustainable development: exploring the theoretical divide. Journal of Sustainable Tourism, 8(1), 1-19.

[22] Elbe, J. (2003) Att sälja Småland - Destinationsmarknadsföring inötverksperspektiv (Selling Småland - Destination marketing in a network perspective). In: M. Larsson (Ed.), Svensk Turismforskning. (Swedish Tourism Research) (Östersund, Sweden: ETOUR).

[23] von Friedrichs Grängsjö, (2003), "Destination networking”, International Journal of Physical Distribution \& Logistics Management, 33, 427-448.

[24] Sörensson, A., Friedrichs, Y. (2013). An importance-performance analysis of sustainable tourism: A comparison between international and national tourists. Journal of Destination Marketing \& Management, 2(1), 14-21.

[25] Edited by Brebbia, C. A., Pineda, F.D., (2004, 2006, 2008, 2010, 2012). Sustainable Tourism I-V. WIT press.

[26] Edited by Brebbia, C. A., Favro, S., Pineda, F.D., (2014). Sustainable Tourism VI. WIT press.

[27] Schultz, P.W., Shriver, C., Tabanic, J.J., Khazian, A. M., (2004). Implicit connections with nature. Journal of Environmental Psychology, 24, 31-42.

[28] Dunlap, R.E., Van Liere, K.D., Mertig, A.G., Jones, R.E. (2000). Measuring endorsement of the new ecological paradigm: a revised NEP scale. Journal of Social Issues, 56(5), 425-442.

[29] Xu, F.F., Fox, D. (2014). Modelling attitudes to nature, tourism and sustainable development in national parks: A survey of visitors in China and the UK. Tourism Management 45(2014) 142-158.

[30] Bandura, A. (1986). Social foundations of thought and action: A social cognitive theory. Englewood Cliffs, NJ: Prentice-Hall.

[31] Bandura, A. (1991). Social cognitive theory of moral thought and action. In W. M. Kurtines, Gewirtz, J.L. (Eds.) Handbook of moral behaviors and development, Vol. 1, PP. 45-103. Hillsdale, NJ: Erlbaum.

[32] Bandura, A. (2000). Exercise of human agency through collective efficacy. Current Direction in Psychological Science, 9(3), 75-78.

[33] Bandura, A. (2002). Social cognitive theory in cultural context. Applied Psychology, 51(2), 269-290.

[34] Font, X., Garay, L., Jones, S. (2016). A social cognitive theory of sustainability empathy. Annals of Tourism Research 58(2016) 65-80.

[35] Ryan, C. (2002). From motivation to assessment. In C. Ryan (Ed.) The tourist experience (PP.58-77) (2nd.) London: Continuum.

[36] Williams, C., Buswell, J. (2003). Service quality in leisure and tourism. UK: CABI Publishing. 
[37] Ballantyne, R., Packer, J., Falk, J. (2011). Visitors' learning for environmental sustainability: Testing short-and long-term impacts of wildlife tourism experiences using structural equation modelling. Tourism Management, 32(6), 1243-1252.

[38] Liang, J.C.H., Tsai, C.Y. (2008). A study of relationship among tourist motivation, experience, satisfaction and revisiting intention of Penghu Ecotourism. Journal of Sport and Recreation Research, 2(3), 94-109.

[39] Williams, P., Soutar, G.N. (2009). Value, satisfaction and behavioural intentions in an adventure tourism context. Annals of Tourism Research, 36(3), 413-438.

[40] Kao, Y.F., Huang, L.S., Wu, C.H. (2008). Effects of theoretical elements on experiential quality and loyalty intentions for theme parks. Asia Pacific Journal of Tourism Research, 13 (2), 163-174.

[41] Choudhury, N. (2014). World Wide Web and its journey from Web 1.0 to Web 4.0. International Journal of Computer Science and Information Technology, 5(6).

[42] Kaplan, A.M., Haelein, M. (2016). Users of the world, unite! The challenges and opportunities of social media. Business Horizons, 53(1), 61 .

[43] Cohen, H. (2011). 30 social media definitions. Posted by Heidi Cohen on May 9, 2011 in actionable marketing social media 101. Available from: http://heidicohen.com/social-media-definition/. Accessed on 10 Feb, 2016.

[44] Krumay, B., Brandtweiner, R. Zauner, C. (2011). The impact of virtual communities on e-loyalty: a conceptual framework. International Journal of Internet Marketing and Advertising, 6(3) 300-314.

[45] Gretzel, U., Fesenmaier, D., O'Leary, J. (2006). The transformation of consumer behaviour. Tourism Business Frontiers: Consumers, Product and Industry, 9-18.

[46] Wang, Y., Yu, Q., Fesenmaier, D.R. (2002). Defining the virtual tourist community: Implications for tourism marketing. Tourism Management, 23(4).

[47] Zeng, B.X., Gerristen, R. (2014). What do we know about social media in tourism? A review. Tourism Management Perspective 10, 27-36.

[48] Fotis, J. (2012). Discussion of the impacts of social media in leisure tourism: "The impact of social media on consumer behaviour: Focus on leisure travel". Available online: http://johnfotis.blogspot.lt/p/ projects.html. Accessed on 12, Feb, 2016.

[49] Bradbury, K. (2011). Blogbury>academic writing >analysis paper: Fall 2011: The growing role of social media in tourism marketing (COMM 427). Available online: http://kelseybradbury.weebly.com/uploads/1/0/9/2/ 10927387/tourismsocialmedia-comm427.pdf. Accessed on 12, Feb, 2016.

[50] Gretzel, U., Yoo, K. (2008). Use and impact of online travel reviews, In P. O'Connor, W. Hopken, Gretzel, U. (Eds), Information and communication technologies in tourism 2008. Vienna, Austria: Springer-Verlag Wien. 
[51] Hudson, S., Thal, K. (2013). The impact of social media on the consumer decision process: Implications for tourism marketing. Journal of Travel \& Tourism Marketing, 30(1/2), 156-160.

[52] Kane, K., Chriu, C., Ciuchete, S.G. (2012). Exploring the eco-attitudes and buying behaviour of Facebook users. Amfiteatru Economic, 14(31), 157171.

[53] Litvin, S.W., Goldsmith, R.E., Pan, B. (2008). Electronic word-of-mouth in hospitality and tourism management. Tourism Management, 29(3), 458-468.

[54] Park, Y.A., Gretzel, U. (2007). Success factors for destination marketing web sites: a qualitative meta-analysis. Journal of Travel Research, 46(1), 46-63.

[55] Zhu, M., Lai, S. (2009). A study about the WOM influence on tourism destination choice. Electronic Commerce and Business Intelligence. EUBI.

[56] Black, H. G., Kelley, S.W. (2009). A storytelling perspective on online customer reviews reporting service failure and recovery. Journal of Travel \& Tourism Marketing, 26(2), 169-179.

[57] Mauri, A.G., Minazzi, R. (2013). Web reviews influence on expectations and purchasing intentions of hotel potential customers. International Journal of Hospitality Management, 34(6), 99-107.

[58] Patterson, I. (2007). Success factor for destination marketing web sites: a qualitative meta-analysis. Journal of Travel Research, 46(1), 46-63.

[59] Confente, I. (2015). Twenty-five years of word-of-mouth studies: a critical review of tourism research. International Journal of Tourism Research, 17(6), 613-624.

[60] Tussyadiah, I.P., Fesenmaier, D.R., Lew, A.A., Duval, D.T. (2008). Marketing places through first-person stories - an analysis of Pennsylvania road tripper blog. Journal of Travel \& Tourism Marketing, 25(3), 299-311.

[61] Kim, M., Newth, D., Christen, P. (2013). Entropy: Modeling dynamics of diffusion across heterogeneous social networks: News diffusion in social media, 15(10), 4215-4242.

[62] Kwon, Y.S., Kim, S.W., Park, S., Lim, S.H., Lee, J.B. (2009). The information diffusion model in the blog world. In proceedings of the $3 \mathrm{rd}$ workshop on social network mining and analysis.

[63] Kotler, P., Kartajaya, H., Setiawan, I. (2010). Marketing 3.0. John Wiley \& Sons, Inc.

[64] Florès, L. (2014). How to Measure Digital Marketing: Metrics for Assessing Impact and Designing Success. Palgrave Macmillan.

[65] Mcintosh, A. J., Siggs, A. (2005). An exploration of the experiential nature of boutique accommodation. Journal of Travel Research, 44(1), 74-81. 